\title{
Герасименко И.В.
}

\section{Позитивные и негативные стратегии вежливости в научном дискурсе}

Северо-Восточнылй государственнылй университет

(Россия, Магадан)

doi: $10.18411 /$ sr-10-02-2019-23

idsp: sciencerussia-10-02-2019-23

\section{Аннотация}

В данной статье автор обращается к социопрагматической категории вежливости, которая является одной из самых важных категорий коммуникативного сознания, и рассматривает ее на материале научного дискурса. Анализ позитивных и негативных стратегий вежливости в научном дискурсе показал, что существует ряд факторов, которые влияют на выбор той или иной стратегии вежливости, а именно: носитель/неноситель языка; опытность/неопытность автора; степень импозиции.

Ключевые слова: научный дискурс, социопрагматическая категория вежливости, негативная вежливость, позитивная вежливость

\section{Abstract}

In this article the author turns to the sociopragmatic category of politeness, which is one of the most important categories of communicative consciousness, and examines it on the basis of scientific discourse. An analysis of positive and negative strategies of politeness in scientific discourse has shown that there are a number of factors that influence the choice of a particular politeness strategy, namely: native / non-native speaker; experienced / inexperienced author; degree of imposition.

Keywords: scientific discourse, sociopragmatic category of politeness, negative politeness, positive politeness

Социопрагматическая категория вежливости является одной из самых важных категорий коммуникативного сознания, и представляет собой ряд аспектов, которые рассматриваются только из соотнесенности с коммуникантами как носителями определенной культуры [Rathmayr, 1996].

П. Браун и С. Левинсон в своей теории трактуют вежливость как сохранение лица и называют лищо универсальным понятием, представляющим собой своеобразный социальный имидж, в сохранении которого заинтересован каждый член общества [Brown, Levinson, 1978: 66]. С целью сохранения лица вежливость реализуется посредством определенных стратегий в различных видах дискурса. В данной статье мы обратились к научному дискурсу и попытались выделить факторы, которые влияют на выбор той или иной стратегии в этом виде дискурса.

Анализ позитивных и негативных стратегий вежливости в научном дискурсе [Герасименко, Деева, 2018] показал, что существует ряд факторов, которые влияют на выбор той или иной стратегии, негативной или позитивной.

К первому фактору относится, то является ли автор носителем или не носителем английского языка. В научных статьях носителей преобладает использование негативных стратегий вежливости и позитивных стратегий вежливости у не носителей языка.

Например:

At the outset, it should be noted that I use "address term" in this work to refer to an expression used in a face-to-face situation to designate an addressee (Oyetade, 1995), given that, as Dickey (1997) points out, a term that is used for an addressee in a dyadic encounter may not necessarily be the same as the one used in the absence of the same addressee. In what follows, I introduce the conceptual framework of the paper, focusing on key notions and the relevant literature. Thereafter, I describe the research design, followed by a discussion of 
the findings. The findings are then interpreted in terms of their implications in the concluding section.

В данном примере мы видим, как в одном отрывке преобладает использование носителем языка сразу нескольких негативных стратегий вежливости. Это употребление пассивного залога, который помогает автору дистанцироваться от высказывания и создать объективность, и персонализация, с помощью которой автор берет на себя ответственность, выражает свою личную позицию.

В то время как в научных статьях, написанных не носителем языка, а точнее, мы рассматривали статьи носителей русского языка, которые пишут их на английском языке, наблюдается преобладание использования позитивных стратегий вежливости.

Например:

In conclusion we would like to stress the following: we cannot deny the fact that we live in the age of information revolution. There are many changes in our daily lives. Young people today are crazy about computers and spend about as much time in front of a television as in a classroom. Teachers today understand they have to make lessons fastmoving and entertaining to capture the attention of students raised on television and computer games. But we should not forget that wisdom comes not from keeping up-to-date or storing facts in our memory but from quiet reflection on books. What is most valuable and above any fashionwe mean things like morality and compassion, - can be found only within us. So, while embracing the future we should remain loyal to our unchanging humanity. While trying to be up-to-date we should not be afraid to remain traditional in our teaching methods.

Здесь присутствует подход «от человека к человеку», что подтверждается использованием местоимений we, our для большего вовлечения читателей, а также модальные глаголы would, can, should, которые автор использовал для выражения смягчения.

При написании научных статей носители и не носители языка опираются на нормы вежлтвости собственного языка, от этого и зависит употребление той или иной стратегии вежливости.

Во-вторых, использование стратегий вежливости во многом определяется опытностью в научном дискурсе. В том случае, если мы имеем дело с первичными научными публикациями, здесь авторы больше прибегают к использованию позитивных стратегий вежливости.

Например:

Citation is used as a measure to rank academics and institutions on the assumption that the more one is cited, the greater the impact of one's research. For this reason, citations in high impact journals that appear on highly regarded scientific indices are favored as sites for publishing one's work. There can be no doubt that citation in the academy is a politicized practice. In acquiring advanced academic literacy, students have to master the art of positioning themselves in relation to the work of others, so that they develop their own 'scholarly identity'. Drawing on insights from sociology of knowledge, information science, and critical discourse analysis, in this paper, we examine the reference lists of ten doctoral theses, from three disciplines - Animal, Plant and Environmental Sciences, Literature, and Sociology - in a leading South African university.

Автор приведенного выше отрывка является молодым ученым. Это одна из его первых публикаций. Здесь автор, в силу своей неопытности, больше прибегает к позитивным стратегиям вежливости, используя спекулятивное выражение on the assumption, претендуя на общую точку зрения с аудиторией, модальный глагол can для подтверждения того, что автор не навязывает свое мнение и местоимение we для установления более тесной связи с аудиторией.

А для более опытных авторов характерно дистанцироваться от материала, приводить большое количество достоверной информации, с помощью которой они раскрывают материал в контексте проявления негативной вежливости. Следующий пример взят из научной статьи профессора филологических наук. 
Indeed, besides the fact that university students constitute a homogeneous group in terms of their obvious rationale in desiring to be members of the university - to learn, thus assuming peripheral participation in academia - they are likely to be involved in a "joint negotiated enterprise; and a shared repertoire of negotiable resources accumulated over time" (Wenger, 1998: 76). That is, students are likely to develop linguistic resources (here, a lexicon of address terms) which will distinguish them from other members of the university community - faculty and non-academic staff.

В данном примере мы видим, как автор дважды использует наречиеопределение likely, тем самым подчеркивая степень уверенности в своем высказывании. Также автор использует пассивную конструкцию to be involved, чтобы подчеркнуть дистанцию и создать объективность.

В-третьих, на выбор стратегий вежливости влияет и степень импозиции. Под импозицией мы понимаем степень новизны предлагаемого научного видения той или иной проблемы. Чем новее и смелее авторское предположение, тем больше он использует позитивных стратегий вежливости.

Например:

We present a new statistical method to derive the evolutionary timeline of molecular clouds and star-forming regions. By quantifying the excess or deficit of the gas-to-stellar flux ratio around peaks of gas or star formation tracer emission, we directly measure the relative rarity of these peaks, which allows us to derive their lifetimes. We present a step-by-step, quantitative description of the method and demonstrate its practical application. We show that the results are robust for a wide variety of gas and star formation tracers, spatial resolutions, galaxy inclinations, and galaxy sizes. Finally, we demonstrate that our method can be applied out to high redshift with a feasible time investment on current large-scale observatories. This is a major shift from previous studies that constrained the physics of star formation and feedback in the immediate vicinity of the Sun.

Здесь мы видим использование автором местоимения we, модального глагола can, что является показателями позитивной вежливости и сопутствующие им глаголы to present, to show, to demonstrate, с помощью которых мы понимаем, что автор вводит и объясняет новую информацию.

Несколько иначе дело обстоит тогда, когда информация дополняет прежние исследования.

R. Hanvey describes several levels of cross-cultural informational awareness: awareness of superficial or very visible cultural traits (stereotyping); awareness of significant and subtle highly contrastive traits; and awareness of an insider's point of view of a given culture. Hanvey correlates methods of learning and interpretation with these levels. Thus, Level 1 is likely associated with using secondary sources of information and a usual feeling of "Oh!Wow!"; Level 2 is associated with "going native", or total immersion and becoming bicultural.

В данном примере автор говорит об исследовании другого ученого и описывает его со своей точки зрения, используя негативную стратегию вежливости употребление наречия-определения likely.

Таким образом, можно сделать вывод, что все три фактора (носитель/ неноситель языка; опытность/неопытность автора; степень импозиции) в равной степени оказывают влияние на выбор стратегий речевой вежливости.

1. Герасименко И. В. Способы реализации стратегий вежливости в научном дискурсе / И. В. Герасименко, И. В. Деева // Инновационные подходы в современной науке: сб. ст. по материалам XXII Международной научно-практической конференции. - М.: Интернаука, 2018. - № 10(22). - 132 с.

2. Brown P., Levinson S. Universals in language usage: politeness phenomena // Ester Goody (ed.). Questions and Politeness: strategies in social interaction. - N. Y.: Cambridge University Press, 1978. - Pp. 56-311.

3. Rathmayr R. Hoflichkeit als kulturspezifisches Konzept: Russisch im Vergleich // Wechselbeziehungen zwischen slavischen Sprachen, Literaturen und Kulturen in Vergangenheit und Gegenwart. - Innsbruck, 1996. - Pp. 174-185. 